\title{
AC 2012-2996: PROPOSING A FRAMEWORK FOR RESTRUCTURING AN INTRODUCTORY ENGINEERING MANAGEMENT COURSE FOR UNDERGRADUATES
}

\section{Dr. Kathryn D. Abel, Stevens Institute of Technology}

Kate Abel serves as the Director of engineering management in the School of Systems and Enterprises at Stevens Institute of Technology. She holds a Ph.D. in technology management and applied psychology. She has been both the President of the Engineering Management Division of ASEE and the President of Epsilon Mu Eta, the Engineering Management Honor Society. She teaches courses in Engineering Economics, Entrepreneurial Analysis of Engineering Design, Total Quality Management, Statistics for Engineering Managers, Engineering Management, and Senior Design. Her research areas include knowledge engineering, as well as, knowledge and information management. She has published more than 20 refereed journal articles, book chapters, and conference papers.

\section{Dr. Anirban Ganguly, Stevens Institute of Technology}

Anirban Ganguly is a lecturer with the School of Systems and Enterprises at Stevens Institute of Technology. He obtained his Ph.D. in engineering management from Stevens Institute of Technology in 2009. He also has a M.S. from Stevens in technology management and a M.B.A. from the University of Calcutta, India. His major research interest comprises innovation and technology management, enterprise agility, knowledge management, and risk management. He has co-authored more than 25 journal and conference papers, a workbook on the use of Excel in engineering economics, and two book chapters. He is one of the chapter authors for the Engineering Management Handbook. 


\section{PROPOSING A FRAMEWORK FOR RESTRUCTURING AN INTRODUCTORY ENGINEERING MANAGEMENT COURSE FOR UNDERGRADUATES}

Engineering Management (EM) is concerned with the application of engineering principles to the domain of business, project and process management. With the varied and expanding employment opportunities available to an Engineering Manager, it is more important than ever for the EM undergraduate to have an understanding of what his major encompasses, including its utility as a practical discipline, as well as, the advantages it provides within industry. The purpose of this paper is to propose a framework for restructuring an existing introductory EM course for the undergraduate Engineering Management population. The goal of the new course is the same as that of the existing introductory EM course; to effectively communicate what EM is and all that it encompasses within one semester's time. However, the revised version of the course is approached with the intention of improving the course's quality and appeal, as well as its' overall effectiveness in conveying the different aspects of EM to the sophomore level audience.

The paper proposes the use of failure analysis, and the mapping of it to various EM topics, in order to introduce EM to the undergraduates from a different perspective than the traditional one. The goal being to intrigue the student with how EM practices could have been used, or used better, to have avoided the failure. The process of restructuring the Undergraduate course titled 'Management of Engineering \& Technology' at Stevens Institute of Technology is used as an illustrative example to validate the framework. The paper concludes with the findings. In addition, recommendations are provided.

Keywords: Engineering Management (EM), Introductory EM course, Failure analysis

\section{Introduction}

Engineering Management can be stated as a specific domain of engineering that focuses on the quantitative analysis of physical assets and processes. The blurring boundaries between management and engineering have led to a large number of graduate engineering managers being part of project teams that involve a substantial amount of pure management activities involved in 
them ${ }^{l}$. An Engineering Manager can be distinguished from other managers as someone uniquely qualified for two types of jobs - the management of technical functions (such as design or production) in almost any organization, or the management of broader functions (such as marketing or top management) in a high-technology enterprise ${ }^{2}$. As a result, it has become imperative for an undergraduate EM program to introduce to its' students the broad concept of Engineering Management; making students aware of opportunities in their field, as well as, their responsibilities once they graduate and join industry.

Review of other university's introductory courses on EM indicated the necessity for developing an introductory course on EM that deviates from the traditional path. Something more innovative, and subsequently more attractive to the undergraduate population was needed. It was seen that almost all the courses injected the students with a heavy dose of traditional theoretical concepts, which often made it highly monotonous to the students, in the process leading to a huge loss of interest in the course itself, and potentially the EM program as well. As a result, it was thought by the current researchers to develop a course which, in spite of harboring in it all the necessary (and relevant) theoretical concepts that a graduating Engineering Manager is required to know, tries to make the course more attractive (and interesting) by following a nontraditional structure - mapping one or more major failures / disasters to various aspects of EM tasks and discussing the EM activities by analyzing the failures themselves.

The purpose of the paper is to propose a framework for restructuring existing introductory EM courses for undergraduates with a special focus on failure analysis. Beginning with a brief discussion on EM and failure analysis, the paper goes on to suggest a possible framework for restructuring a sophomore level introductory undergraduate course on EM. Major man-made failures and disasters would be used as guiding examples for analyzing the various EM activities discussed in the course. The project undertaken at Stevens Institute of Technology to restructure the course titled 'Management of Engineering \& Technology' is used as an illustrative example to explain the proposed model. The authors hope that the proposed framework in this research article would serve an important catalyst to the educators who are currently (or in the future) involved in an endeavor to restructure, or create, a course to introduce EM undergraduates to the basic technical and managerial activities required to manage engineering and technological projects. 


\section{A Brief History of Engineering Management}

Engineering Management is a unique discipline that uses engineering skills and knowledge in managing large scale projects. It links all other types of engineering, from civil and mechanical to chemical and electrical, in accomplishing organizational results through the leadership of knowledge-workers and the appropriate application of technology ${ }^{1}$. Therefore, as seen from the definition itself, EM has its roots in both traditional engineering, as well as, the management disciplines, therefore making it important to both academicians, as well as, practitioners. EM as a formal degree has been present since the mid 1940s ${ }^{3}$ and currently, there are more than 100 universities in the US offering an undergraduate and / or graduate program in EM. EM programs were historically embedded within the departments of industrial engineering, depending upon the universities ${ }^{4}$. However, in order to reflect the gradual shift from manufacturing to turn-key systems integrators in a global economic environment, many more universities are aligning their EM programs with their systems engineering program ${ }^{5}$.

\section{Importance of Analyzing Failures}

Failure analysis is the process of collecting and analyzing data to determine the cause of a failure. It relies on collecting failed components for subsequent examination of the cause or causes of failure using a wide array of methods. Organizations cannot learn from failures unless a thoughtful analysis and discussion of failure occurs ${ }^{6}$. Analyzing failures provides a unique opportunity for engineering managers to learn. Analyzing failures may bring new perspectives and insights that deepen knowledge and help to counteract self-serving biases that may color the perceptions of those most directly involved in the failure ${ }^{6}$. Additionally, analysis of failures aids an organization in identifying the various areas of engineering and managerial activities that need to be monitored and assessed on a regular basis. Therefore, it is hoped that mapping the various activities involved in the management of engineering and technology with well known failures will enable the undergraduate EM students to get a better and deeper understanding of the topics associated with managing engineering and technological projects and processes, and the degree to which they are critical to it's success.

\footnotetext{
${ }^{1}$ Definition by American Society of Engineering Management
} 


\section{Proposed Framework for the Introductory Course on Engineering Management}

As stated earlier, the primary objective of this paper was to propose a framework for developing an undergraduate introductory EM course that teaches much of what EM encompasses, which might also intrigue a sophomore level audience. This type of course is included in the curriculum of many university EM programs, country-wide. However, talking to other universities indicated that few were satisfied with their current Introductory EM courses. Many were looking to improve their Introductory EM course, but just did not know the best way to proceed. The authors believe that failure analysis may hold the key to drawing the young undergraduates into the intricacies of EM. Therefore, the first step of the research was to identify major areas where EM is employed. The second step was to brainstorm a set of famous "failures". The third step was to map important causes of failures onto various EM activities / topics. The identified set of possible causes of failures was arrived through an in-depth review of the available literature as well as discussions with subject matter experts. The identified set of failures, in no particular order, is illustrated in Table 1.

Table 1: A set of important causes of failures

\begin{tabular}{|c|c|}
\hline & Important causes of failures \\
\hline 1 & Failure in communication \\
\hline 2 & Quality related failures \\
\hline 3 & Failure in leadership \\
\hline 4 & Failure in teamwork \\
\hline 5 & Failure in flexibility / agility \\
\hline 6 & Failure in Knowledge Management \\
\hline 7 & Failure in quantitative analysis \\
\hline 8 & Economic / budgetary failure \\
\hline 9 & Technology related failure \\
\hline 10 & Systems Engineering management failure \\
\hline 11 & Failure in engineering ethics \\
\hline
\end{tabular}


After the important causes of failures were identified, as well as, activities critical to the EM discipline, the next stage was to map them to each other. This is exhibited in Table 2.

Table 2: Mapping the EM topics to causes of failures

\begin{tabular}{|c|c|c|}
\hline & Important causes of failures & EM topics \\
\hline 1 & Failure in communication & $\begin{array}{l}\text { Communication for Engineering Managers; } \\
\text { Planning and organizing EM projects }\end{array}$ \\
\hline 2 & Quality related failures & Quality control for engineering managers \\
\hline 3 & Failure in leadership & $\begin{array}{l}\text { Leadership in Engineering Management; } \\
\text { Leaders versus managers }\end{array}$ \\
\hline 4 & Failure in teamwork & Teamwork in Engineering management \\
\hline 5 & Failure in flexibility / agility & $\begin{array}{l}\text { Flexibility in Managing Engineering and } \\
\text { Technology projects }\end{array}$ \\
\hline 6 & Failure in Knowledge Management & $\begin{array}{l}\text { Knowledge Management for Engineering } \\
\text { Management }\end{array}$ \\
\hline 7 & Failure due to incorrect quantitative analysis & Quantitative Analysis for EM \\
\hline 8 & Economic / budgetary failure & $\begin{array}{l}\text { Cost accounting for EM; Financial analysis } \\
\text { for EM }\end{array}$ \\
\hline 9 & Technology related failure & $\begin{array}{l}\text { Technology and innovation for engineering } \\
\text { managers }\end{array}$ \\
\hline 10 & Systems Engineering management failure & $\begin{array}{l}\text { Systems engineering management for } \\
\text { engineering managers }\end{array}$ \\
\hline 11 & Failures in engineering ethics & Ethics in engineering management \\
\hline
\end{tabular}

The third and the final step of the research involved developing a course based on the information collected and illustrated in Tables 1 and 2. The course is completing its' developmental stage and is to be taught for the first time in spring 2012. Appendix A of the research paper provides the reader with a copy of the spring 2012 course syllabus. It was also thought worthwhile by the authors to provide a table illustrating some of the failures that would be discussed with the students with the intention of mapping them to various EM topics - 
thereby making the structure of the lecture more interesting in the process. This is exhibited in Table 3.

Table 3: Causes of failures with Examples

\begin{tabular}{|c|c|c|}
\hline & Important causes of failures & Example(s) \\
\hline 1 & Failure in communication & $\begin{array}{l}\text { Challenger space shuttle disaster, Airline accidents } \\
\text { ( Tenerife airport disaster) }\end{array}$ \\
\hline 2 & Quality related failures & $\begin{array}{l}\text { BP oil spill, Therac } 25 \text { (the computerized radiation } \\
\text { therapy machine) }\end{array}$ \\
\hline 3 & Failure in leadership & $\begin{array}{l}\text { Exxon Valdez Oil Spill - Joseph Hazelwood, the person } \\
\text { selected to be the ships leader, consumed alcohol and } \\
\text { retired to his cabin to sleep it off prior to his ship } \\
\text { colliding with a reef }\end{array}$ \\
\hline 4 & Failure in teamwork & $\begin{array}{l}\text { The } 1981 \text { Hyatt Regency bridge collapse in Kansas City } \\
\text { resulted from a failure of the designer and the contractor } \\
\text { being able to work as a team, Operation Market Garden - } \\
\text { an unsuccessful allied military operation during WW II }\end{array}$ \\
\hline 5 & Failure in flexibility / agility & CD vs. mp3 downloads; Itunes \\
\hline 6 & $\begin{array}{l}\text { Failure in Knowledge } \\
\text { Management }\end{array}$ & Challenger space shuttle disaster \\
\hline 7 & $\begin{array}{l}\text { Failure due to incorrect } \\
\text { quantitative analysis }\end{array}$ & $\begin{array}{l}\text { The Patriot Missile failure in Saudi Arabia (the Scud } \\
\text { struck an American Army barracks, killing } 28 \text { soldiers } \\
\text { and injuring around } 100 \text { other people), Explosion of } \\
\text { Ariane } 5 \text { rocket }\end{array}$ \\
\hline 8 & Economic / budgetary failure & $\begin{array}{l}\text { Fukushima Nuclear Accident - Using cheap products to } \\
\text { save money }\end{array}$ \\
\hline 9 & Technology related failure & $\begin{array}{l}\text { The magically moving Millennium Bridge in London, } \\
\text { Concorde disaster }\end{array}$ \\
\hline 10 & $\begin{array}{l}\text { Systems Engineering } \\
\text { management failure }\end{array}$ & Mars Climate Orbiter \\
\hline 11 & Failures in engineering ethics & Bhopal Gas Tragedy: Union Carbide chemical plant \\
\hline
\end{tabular}

Additionally, the students will also be required to complete a weekly survey questionnaire after each lecture / module so that the instructors and the course developers can use student feedback as a part of continuous process improvement. The structured questionnaire will be a blend of ranking and open-ended questions and will require feedback from the students regarding the 
overall quality of the lecture and the discussions / case studies. A sample questionnaire is provided in Appendix B of the paper.

\section{Conclusions}

The authors admit that the set of failures used for the alpha version of this course, to be run in Spring 2012, may not be exhaustive, nor even the best set. However, it is intended that weekly feedback will be sought from the students to determine if the students think they are learning important aspects about EM through each case study. Feedback will be reviewed and summarized in Summer 2012, to ensure that the beta version of the Introductory EM course set for spring 2013, is truly accomplishing the goal of educating, in an interesting and interactive way, the next generation of Engineering Managers. Hopefully, the sophomores in spring 2013 (and 2012 if we've done it right) will not only come to know the varied aspects of the EM discipline, but will understand there can often be alternative ways to solve a problem, and that approaching a project/process/problem from a multi-disciplinary angle, such as occurs often with EM, may lead to the most plausible and useful answer.

\section{Bibliography}

1. Abel, Kathryn D. and A. Ganguly, "Evaluating Quality Management Courses in Graduate Engineering Management Curriculums," 2011 ASEE Annual Conference and Exposition, Vancouver, Canada, June 2011

2. Lannes, William J., "What is Engineering Management?, ” IEEE Transactions on Engineering Management, 48(1), February 2001, pp. 107-110

3. Kocaoglu, D., "Strategic opportunities for Engineering Management," PICMET '91 Portland International Conference on Management of Engineering and Technology, 1991, pp. 78-83

4. Farr, John V., and T. Kotnour, "Engineering Management: Past, Present and Future," Engineering Management Journal, 17(1), March 2005, pp. 15 - 26

5. Farr, John V., and D. Beude, "Systems Engineering and Engineering Management: Keys to the Efficient Development of Products and Services," Engineering Management Journal, 15(3), September 2003, pp. 3 - 11 
6. Edmondson, Amy and Cannon, Mark D., "The Hard Work of Failure Analysis," HBS Working Knowledge, August 22, 2005 


\section{Appendix A:}

\section{Management of Engineering and Technology: Spring 2012 Course Syllabus}

\begin{tabular}{|c|c|c|c|}
\hline $\begin{array}{l}\text { Date } \\
\text { Tue }\end{array}$ & $\begin{array}{l}\text { Date } \\
\text { Thu }\end{array}$ & Week \# & Topic \\
\hline & $1 / 19$ & 1 & Course Introduction, and Intro. to EM and failure analysis \\
\hline \multirow[t]{2}{*}{$1 / 24$} & & 2 & Team Meeting \\
\hline & $1 / 26$ & 2 & Ethics in Engineering Management (Chapter 11) \\
\hline \multirow[t]{2}{*}{$1 / 31$} & & 3 & Project Topic Review with TA \\
\hline & $2 / 2$ & 3 & Communication in Engineering Management \\
\hline \multirow[t]{2}{*}{$2 / 7$} & & 4 & Team Meeting \\
\hline & $2 / 9$ & 4 & $\begin{array}{l}\text { Importance of Leadership in Engineering Management } \\
\text { (Chapters } 4 \text { \& 10) }\end{array}$ \\
\hline \multirow[t]{2}{*}{$2 / 14$} & & 5 & $\begin{array}{l}\text { Systems Engineering and its role in Eng. \& Management } \\
\text { (Guest Lecture by Eric Hole) }\end{array}$ \\
\hline & $2 / 16$ & 5 & Team Meeting \\
\hline \multirow[t]{2}{*}{$2 / 21$} & & 6 & NO CLASS - MONDAY SCHEDULE \\
\hline & $2 / 23$ & 6 & QUIZ 1, Lectures 1 - 5- on-line \\
\hline \multirow[t]{2}{*}{$2 / 28$} & & 7 & Team Meeting \\
\hline & $3 / 1$ & 7 & $\begin{array}{l}\text { Quality Management for Engineering Managers } \\
\text { (Guest Lecture by Dr. Donald N. Merino) }\end{array}$ \\
\hline \multirow[t]{2}{*}{$3 / 6$} & & 8 & Team Meeting \\
\hline & $3 / 8$ & 8 & Financial Analysis for Engineering Managers \\
\hline $3 / 13$ & $3 / 15$ & - & SPRING BREAK (NO CLASS) \\
\hline \multirow{2}{*}{$3 / 20$} & & 9 & Team Meeting \\
\hline & $3 / 22$ & 9 & Knowledge Management and Teamwork for Engineering Managers \\
\hline \multirow[t]{2}{*}{$3 / 27$} & & 10 & Team Meeting \\
\hline & $3 / 29$ & 10 & $\begin{array}{l}\text { Globalization and Global Sourcing (Chapter 13) } \\
\text { (Guest Lecture by Dr. Jimmy Gandhi) }\end{array}$ \\
\hline \multirow[t]{2}{*}{$4 / 3$} & & 11 & Team Meeting \\
\hline & $4 / 5$ & 11 & Quantitative Analysis for Engineering Managers \\
\hline \multirow[t]{2}{*}{$4 / 10$} & & 12 & Marketing and Organizational Flexibility for Engineering Managers \\
\hline & $4 / 12$ & 12 & $\begin{array}{l}\text { QUIZ 2, Lectures } 6 \text { - } 11-\text { in class } \\
\text { (Closed book and notes) }\end{array}$ \\
\hline \multirow[t]{2}{*}{$4 / 17$} & & 13 & Team Meeting \\
\hline & $4 / 19$ & 13 & Supply Chain Management for Engineering Managers \\
\hline \multirow[t]{2}{*}{$4 / 24$} & & 14 & Project Oral Presentations (15 min. each) \\
\hline & $4 / 26$ & 14 & Project Oral Presentations (15 min. each) \\
\hline $5 / 1$ & & & $\begin{array}{l}\text { Project Oral Presentations (15 min. each) } \\
\text { (Distribute and Collect Team Evaluations) }\end{array}$ \\
\hline
\end{tabular}




\section{Appendix B:}

A weekly feedback form to assess the quality of the course and the case studies

Name:

Topic / Lecture Theme:

Please indicate the level of importance of each question listed below on a scale of $1-5$, with 1 being strongly disagree and 5 being strongly agree.

\begin{tabular}{|c|c|c|c|c|c|c|}
\hline \multicolumn{7}{|c|}{ QUESTIONS } \\
\hline & & $\begin{array}{c}1 \\
\text { Strongly } \\
\text { Disagree }\end{array}$ & 2 & 3 & 4 & $\begin{array}{c}\mathbf{5} \\
\text { Strongly } \\
\text { Agree } \\
\end{array}$ \\
\hline 1 & $\begin{array}{l}\text { The topic covered in lecture was organized in } \\
\text { a way that helped my learning }\end{array}$ & $\square$ & $\square$ & $\square$ & $\square$ & $\square$ \\
\hline 2 & The failure was relevant to the lecture topic & $\square$ & $\square$ & $\square$ & $\square$ & $\square$ \\
\hline 3 & $\begin{array}{l}\text { The course slides were comprehensive and } \\
\text { well-organized }\end{array}$ & $\square$ & $\square$ & $\square$ & $\square$ & $\square$ \\
\hline 4 & $\begin{array}{l}\text { The in-class discussion was useful and } \\
\text { challenged my intellect }\end{array}$ & $\square$ & $\square$ & $\square$ & $\square$ & $\square$ \\
\hline 5 & $\begin{array}{l}\text { The lecture stimulated my interest in the } \\
\text { topic subject }\end{array}$ & $\square$ & $\square$ & $\square$ & $\square$ & $\square$ \\
\hline 6 & $\begin{array}{l}\text { The lecture helped me to develop my own } \\
\text { ideas regarding failures and mapping of EM } \\
\text { to the topic discussed this week }\end{array}$ & $\square$ & $\square$ & $\square$ & $\square$ & $\square$ \\
\hline
\end{tabular}

Additional questions:

What other failure do you think might be more relevant to the topic?

In what ways did this lecture meet, exceed, or fall short of your expectations? 